\title{
Studies on Genetic Variability, Heritability and Genetic Advance in Bitter Gourd (Momordica charantia L.) for Yield and Yield Contributing Traits
}

\author{
Nidhi Tyagi", V.B. Singh and Praveen Kumar Maurya \\ Department of Vegetable Science, Narendra Deva University of Agriculture and Technology, \\ Kumarganj, Faizabad- 224 229, Uttar Pradesh, India \\ *Corresponding author
}

K e y w o r d s
$\begin{aligned} & \text { Momordica charantia } \\ & \text { L., Variability, } \\ & \text { Heritability, Genetic } \\ & \text { advance }\end{aligned}$
Article Info
$\begin{aligned} & \text { Accepted: } \\ & \text { 16 February } 2018 \\ & \text { Available Online: } \\ & \text { 10 March } 2018\end{aligned}$

\section{Introduction}

Bitter gourd (Momordica charantia L.) is an important cucurbitaceous crop due to its potential to return profit, nutritional value, and production potential. It is also known as bitter melon, bitter gourd, bitter cucumber, bitter squash, balsam pear, karela, cassilla and maiden apple (Morton, 1967). It is adapted to a wide range of environments and can be grown tropical and sub tropical climate (Lim, 1998). The center of origin of this crop is
India, with a secondary center of diversity in China and South East Asia (Grubben, 1977). It is highly cross-pollinated and monoecious in nature, with separate yellow male and female flowers, and exhibits large variations for fruit and vegetative characters (Resmi and Sreelathakumary, 2012). It is a common cucurbit of wild flora of tropical Africa which offers great resources for breeding of cultivated bitter gourd for desirable qualitative traits, tolerance to biotic and abiotic factors etc. Fruits contain a reasonable amount of 
different nutrients such as proteins, carbohydrates, fats, minerals and vitamins (A, $\mathrm{B}_{2}$, and C) (Raja et al., 1984). It contains considerable amount of water (83-92\%), carbohydrates (4.0-10.5\%), protein (1.5$2.0 \%)$, fat $(0.2-1.0 \%)$, minerals $(0.5-1.0 \%)$ and fiber $(0.8-1.7 \%)$.

In India, Momordica charantia have relatively broad phenotypic species variation (i.e., sex expression, growth habit, maturity, and fruit shape, size, colour and surface texture (Behera et al., 2006). Estimates of heritability have to be considered with conjunction with genetic advance and change in mean value among successive generation, alone it do not provide idea about expected gain in next generation (Shukla et al., 2006). For a successful planning of breeding improvement program, the analysis of variability among the traits and their association of a particular character in relation to yield and yield attributing traits it would be great importance (Mary and Gopalan, 2006).

It also gives an estimate of genetic advance a breeder can expect from selection applied to a population and help in deciding on what breeding method to choose (Idahosa et al., 2010). High heritability and high genetic advance for a given trait indicates that it is governed by additive gene action and, therefore, provides the most effective condition for selection (Hamdi et al., 2003). It is possible to develop high-yielding openpollinated varieties, or hybrids, by utilizing existing variability (Islam et al., 2009) and this technique could be used in improvement of bitter gourd. Before aiming at an improvement of yield, it is necessary to have information on genetic variability and heritability, in respect of important characters associated with yield. Therefore, the present study was taken up to obtain information on the range of variability for different important economic traits.

\section{Materials and Methods}

\section{Experimental site and layout}

The experimental material consisted of thirty one genotypes including two check varieties (Pusa Vishes and Pusa Do Mausami), conducted during spring summer season of 2015 at the Main Experiment Station, Department of Vegetable Science, Narendra Deva University of Agriculture and Technology, Kumarganj, Faizabad, Uttar Pradesh, India. The experiment was laid out in RBD (Randomized Block Design) with three replications in individual plot size $(3 \mathrm{~m} \times 2 \mathrm{~m})$. The distance maintained between row to row and plant to plant was $2 \mathrm{~m}$ and $0.50 \mathrm{~m}$, respectively. All recommended agronomic practices for the region were adopted to raise a healthy crop. Five plants were selected randomly from each plot to record observations on 12 characters. Data were recorded on various parameters, viz. node number to anthesis of first staminate flower, node number to anthesis of first pistillate flower, days to anthesis of first staminate flower, days to anthesis of first pistillate flower, days to first fruit harvest, vine length (m), number of nodes per vine, fruit length $(\mathrm{cm})$, fruit diameter $(\mathrm{cm})$, average fruit weight (g), number of fruits per plant and fruit yield per plant $(\mathrm{kg})$.

\section{Statistical analysis}

The analysis of variance for the design of experiment (RBD) was carried out according to the procedure outlined by Panse and Sukhatme (1967).

\section{Estimation of components of variances}

\section{Phenotypic variance $\left(\sigma_{\mathrm{p}}^{2}\right)$}

The phenotypic variance was calculated by following formula as suggested by Burton and 
de Vane (1953). Phenotypic variance $\left({ }^{\sigma_{p}^{2}}\right)=$ $\sigma_{\mathrm{E}_{+}}^{2} \sigma_{\mathrm{e}}^{2}$

Where,

$\sigma_{\mathrm{g}}^{2}=$ Genotypic variance

$\sigma_{\mathrm{e}}^{2}=$ Error variance

Genotypic variance $\left(\sigma_{\mathrm{g}}^{2}\right)$

The mean squires due to errors were subtracted from the mean squire due to genotypes and their difference was divided by replications for obtaining the genotypic variance, which was calculated according to the method suggested by Burton and de Vane (1953).

Genotypic variance $\left(\sigma_{\mathrm{g}}^{2}\right)=\frac{\mathrm{MSg}-\mathrm{MSe}}{r}$

Where,

$\mathrm{MSg}$ = genotype mean square

$\mathrm{MSe}=$ error mean square

$r=$ number of replications

Estimation of genotypic and phenotypic coefficient of variation

The genotypic coefficient of variation (GCV) and phenotypic coefficient of variation (PCV) were computed following Burton and de Vane (1953).

$\mathrm{GCV}=\frac{\text { Genotypic } \quad \text { standard deviation }}{\text { Mean }(\overline{\mathrm{X}})} \times 100$

$\mathrm{PCV}=\frac{\frac{\text { Phenotypic }}{\text { standard deviation }}}{\text { Mean }(\overline{\mathrm{X}})} \times 100$

\section{Estimation of heritability}

Heritability in broad sense $\left(\mathrm{h}^{2}{ }_{\mathrm{bs}}\right)$ was calculated using the formula suggested by Burton and de Vane (1953).

$\mathrm{h}_{(\mathrm{bs})}^{2}=\frac{\sigma^{2} \mathrm{~g}}{\sigma^{2} \mathrm{~g}+\sigma^{2} \mathrm{e}}$ or $\frac{\sigma^{2} \mathrm{~g}}{\sigma^{2} \mathrm{p}} \times 100$

Where,

$h^{2} b s=$ Heritability in broad sense

$\sigma^{2} \mathrm{~g}=$ Genotypic variance

$\sigma^{2} \mathrm{p}=$ Phenotypic variance

\section{Estimation of genetic advance}

The expected genetic advance for different characters under selection was estimated using the formula suggested Johnson et al., (1955).

G.A. $=\frac{\sigma^{2} \mathrm{~g}}{\sigma^{2} \mathrm{ph}} \cdot K \cdot \sigma p$

Or

G.A. $=\mathrm{K} \cdot \mathrm{h}^{2} \cdot \sigma \mathrm{p}$

Where,

$\mathrm{K}=$ Selection intensity, the value which is 2.06 at $5 \%$ selection intensity

$h^{2} b=$ Heritability in broad sense

$\sigma^{2} \mathrm{~g}=$ Genotypic variance

$\sigma^{2} \mathrm{ph}=$ Phenotypic variance

Estimation of genetic advance as percentage of mean

Genetic gain expressed as per cent ratio of genetic advance of population mean was 
calculated by the method given by Johnson et al., (1955).

G.A. $(\%)=\frac{\text { Genetic } \text { adavance }}{\overline{\mathrm{X}}} \times 100$

\section{Results and Discussion}

\section{Analysis of variance}

Analysis of variance for 12 characters (Table 1) of bitter gourd revealed that mean squares due to genotypes were highly significant for all traits under study, thereby suggesting existence of great amount of variation among the genotypes.

So, there is a scope for considerable improvement in the crop through the characters studies such as node number to anthesis of first staminate flower, node number to anthesis of first pistillate flower, days to anthesis of first staminate flower, days to anthesis of first pistillate flower, days to first fruit harvest, vine length (m), number of nodes per vine, fruit length $(\mathrm{cm})$, fruit diameter $(\mathrm{cm})$, average fruit weight $(\mathrm{g})$, number of fruits per plant and fruit yield per plant $(\mathrm{kg})$. Similar to the present findings, significant differences for various characters was reported by Islam et al., (2009), Gupta et al., (2013), Yadav et al., (2013), Pathak et al., (2014) and Singh et al., (2017) in bitter gourd.

\section{Genotypic and phenotypic co-efficient of variation}

The coefficient of genotypic and phenotypic variability is helpful to measure the extent of variability present in particular trait. They also provide a measure to compare the variability present among various quantitative traits. The estimates of coefficient of variability revealed that in general magnitude of phenotypic coefficient of variation for all the traits were higher than the magnitude of genotypic coefficient of variation (Table 2). The estimates of phenotypic as well as genotypic coefficient of variation were observed higher for average fruit weight $(28.70 \%)$ followed by fruit yield per plant $(23.10 \%)$, vine length $(22.56 \%)$ and fruit length $(21.80 \%)$ whereas, node number to anthesis of first staminate flower, number of fruits per plant, node number to anthesis of first pistillate flower, number of nodes per vine and fruit diameter showed moderate coefficient of variability while, days to anthesis of first staminate flower, days anthesis of first pistillate flower and days to first fruit harvest showed the lowest coefficients of variation. Narayan et al., (2006), Raja et al., (2007), Yadav et al., (2013), Pathak et al., (2014), Singh et al., (2017) and Yadagiri et al., (2017) in bitter gourd reported similar trend of variation for genotypic coefficient of variation and phenotypic coefficient of variation of various characters studied which is in conformity with the present findings.

\section{Heritability and genetic advance as per cent of mean}

High heritability accompanied by high genetic advance is more useful than heritability alone and considerable importance could be made in these characters by predicting the result and selecting the best individual (Johnson et al., 1955). Estimates of heritability in broad sense $\left(\mathrm{h}^{2}{ }_{\mathrm{bs}}\right)$ and genetic advance as per cent of mean for twelve characters in bitter gourd genotypes are shown in Table 2.

The estimates of heritability in broad sense $\left(\mathrm{h}_{\text {bs }}^{2}\right)$ ranged from 31.21 percent (vine length) to 92.41 per cent (fruit length). Highest estimates of heritability were observed for all the characters fruit length (92.14), number of nodes per vine (89.27), fruit diameter (82.30), node number to anthesis of first staminate flower (76.3), fruit yield per plant (72.67). 
Table.1 Analysis of variance for twelve metric traits in bitter gourd

\begin{tabular}{|l|}
\multicolumn{1}{|c|}{ Characters } \\
\hline \multicolumn{1}{|c|}{ d.f. } \\
\hline Node number to anthesis of first staminate flower \\
\hline Node number to anthesis of first pistillate flower \\
\hline Days to anthesis of first staminate flower \\
\hline Days to anthesis of first pistillate flower \\
\hline Days to first fruit harvest \\
\hline Number of nodes per vine \\
\hline Vine length (m) \\
\hline Fruit length (cm) \\
\hline Fruit diameter (cm) \\
\hline Number of fruits per plant \\
\hline Average fruit weight (g) \\
\hline Fruit yield per plant (kg) \\
\hline$* *$ significant at $\mathrm{P}<0.01$ level \\
\hline
\end{tabular}

\begin{tabular}{|c|c|c|}
\hline & Source of variation & \\
\hline Replications & Treatments & Error \\
\hline $\mathbf{( 2 )}$ & $\mathbf{( 3 0 )}$ & $\mathbf{( 6 0 )}$ \\
\hline 1.623 & $8.663 * *$ & 0.812 \\
\hline 2.236 & $10.265 * *$ & 1.758 \\
\hline 8.301 & $56.399^{* *}$ & 14.345 \\
\hline 2.032 & $61.777 * *$ & 17.887 \\
\hline 3.333 & $65.277^{* *}$ & 21.368 \\
\hline 13.752 & $183.068 * *$ & 7.052 \\
\hline 0.032 & $0.861 * *$ & 0.027 \\
\hline 1.898 & $33.029 * *$ & 0.879 \\
\hline 0.142 & $0.686 * *$ & 0.045 \\
\hline 1.306 & $44.388^{* *}$ & 10.930 \\
\hline 0.558 & $1533.561 * *$ & 172.610 \\
\hline 0.004 & $0.457 * *$ & 0.050 \\
\hline
\end{tabular}

Table.2 Estimates of genetic parameters of twelve characters of bitter gourd genotypes

\begin{tabular}{|c|c|c|c|c|c|c|}
\hline Characters & Range & $\begin{array}{c}* P C V \\
(\%)\end{array}$ & $\begin{array}{l}* \mathrm{GCV} \\
(\%)\end{array}$ & $\begin{array}{l}\text { Heritability broad } \\
\text { sense }\left(h_{b s}^{2}\right)(\%)\end{array}$ & $\begin{array}{l}\text { Genetic } \\
\text { advance }\end{array}$ & $\begin{array}{l}\text { Genetic Advance in per } \\
\text { cent of mean }\end{array}$ \\
\hline Node number to anthesis of first staminate flower & $6.33-13.00$ & 20.17 & 17.61 & 76.3 & 2.91 & 31.70 \\
\hline Node number to anthesis of first pistillate flower & $9.66-16.33$ & 16.89 & 13.27 & 61.72 & 2.72 & 21.47 \\
\hline Days to anthesis of first staminate flower & $35.00-50.66$ & 12.91 & 9.07 & 49.24 & 5.42 & 13.14 \\
\hline Days to anthesis of first pistillate flower & $40.66-60.66$ & 12.24 & 8.21 & 44.99 & 5.28 & 11.34 \\
\hline Days to first fruit harvest & $53.33-76.00$ & 9.93 & 6.33 & 40.65 & 5.02 & 8.31 \\
\hline Number of nodes per vine & $37.00-67.66$ & 15.50 & 14.65 & 89.27 & 14.90 & 28.51 \\
\hline Vine length $(\mathrm{m})$ & $1.60-3.60$ & 22.56 & 21.55 & 31.21 & 1.03 & 42.39 \\
\hline Fruit length (cm) & $8.10-20.80$ & 21.80 & 20.95 & 92.41 & 6.48 & 41.50 \\
\hline Fruit diameter $(\mathrm{cm})$ & $2.36-4.06$ & 14.73 & 13.36 & 82.30 & 0.86 & 24.97 \\
\hline Number of fruits per plant & $17.96-33.80$ & 19.36 & 13.76 & 50.50 & 4.88 & 20.14 \\
\hline Average fruit weight (g) & $42.43-129.46$ & 28.70 & 24.42 & 72.44 & 37.34 & 42.82 \\
\hline Fruit yield per plant (kg) & $0.85-2.61$ & 23.10 & 19.69 & 72.67 & 0.64 & 34.58 \\
\hline
\end{tabular}


However, node number to anthesis of first staminate flower $(61.72 \%)$ and number of fruit per plant $(50.50 \%)$ which indicated moderate heritability, while days to anthesis of first staminate flower $(49.24 \%)$, days to anthesis of first pistillate flower (44.99\%), days to first fruit harvest $(40.65 \%)$ and vine length $(31.21 \%)$ indicated lower heritability. Results obtained here in agreement with the findings of Islam et al., (2009), Dalamu and Behera (2013), Chakraborty et al., (2013), Pathak et al., (2014) and Yadagiri et al., (2017). Highest estimates of genetic advance in per cent of mean was recorded for average fruit weight $(42.82 \%)$, vine length (42.39) fruit length $(41.50 \%)$, fruit yield per plant $(34.58 \%)$, node number to anthesis of first staminate flower $(31.70 \%)$, while number of nodes per vine $(28.51 \%)$, fruit diameter (24.97\%), node number to anthesis of first pistillate flower $(21.47 \%)$, and number of fruits per plant $(20.14 \%)$ showed moderate genetic advance in per cent of mean, whereas, days to anthesis of first staminate flower $(13.14 \%)$, days to anthesis of first pistillate flower (11.34\%), and days to first fruit harvest $(8.31 \%)$ recorded the lower genetic advance in per cent of mean.

Fruit length $(\mathrm{cm})$, number of nodes per vine, fruit diameter $(\mathrm{cm})$, node number to anthesis of first staminate flower, average fruit weight (g) and fruit yield per plant (kg) had high estimates of heritability coupled with high genetic advance as percent of mean. Hence, these characters need to be given more emphasis in selection as these are expected to be controlled by additive genes.

The breeder should adopt suitable breeding methodology to utilize both additive and nonadditive gene effects simultaneously, since varietal and hybrid development will go a long way in the breeding programmes especially in case of bitter gourd. Similar kind of results in bitter gourd was also reported by several researchers (Raja et al., 2007, Chakraborty et al., 2013; Gupta et al., 2013; Pathak et al., 2014 and Yadagiri et al., 2017).

\section{References}

Behera, T.K., Dey, S.S., and Sirohi, P.S. 2006. 'DBGy-201' and 'DBGy- 202': two gynoecious lines in bitter gourd (Momordica charantia L.) isolated from indigenous source. Indian Journal of Genetics and Plant Breeding. 66: 61-62.

Butron, G.W., and De Vane, E.H. 1953. Estimating heritability in tall-fescue (Festuca arundinacea) from replicated clonalmaterial. Agronomy Journal. 45: 478481.

Chakraborty, L., Acharya, P., and Raychaudhuri, S. 2013. Diversity analysis of Momordica charantia L. accessions from eastern and north eastern India based on morphological, yield related traits and molecular marker. Proceedings of FVHH, Thailand.

Dalamu, D., and Behera, T.K. 2013. Character association and path coefficient analysis of indigenous and exotic bitter gourd (Momordica charantia) germplasm, The Indian Journal of Agricultural Sciences. 83(5): 525-528.

Grubben, G.J.H. 1977. Tropical vegetable and their genetic resources, IBPGR, Rome, pp. 51-52.

Gupta, N., Bhardwaj, M., and Singh, S. 2013. Genetic variability and correlation studies in bitter gourd under mid hill conditions of Himachal Pradesh, National Symposium on Abiotic and Biotic Stress Management in Vegetable Crops. Paper NSAB231

Hamdi, A., El-Ghareib, A.A., Shafey, S.A., and Ibrahim, M.A.M. 2003. Genetic variability, heritability and expected genetic advance for earliness and seed yield from selection in lentil. Egyptian Journal of Agricultural Research. 81: 125-137.

Idahosa, D.O., Alika, J.E., and Omoregie, A.U. 2010. Genetic variability, heritability and expected genetic advance as indices for yield and yield components selection in cowpea [Vigna unguiculata (L.) Walp]. Academia Arena. 2: 22-26. 
Islam, M.R., Hossain, M.S., Bhuiyan, M.S.R., Husna, A., and Syed, M.A. 2009. Genetic variability and path-coefficient analysis of bitter gourd (Momordica charantia L.). International Journal of Agricultural Sustainability. 1(3): 53-57.

Johnson, H.W., Robinson, J.F., and Comstock, R.E. 1955. Estimation of genetic and environmental variability in soya bean. Agronomy journal. 7: 314-318.

Lim, T.K. 1998. Loofahs, gourds, melons and snake beans. The new rural industries.

Rural Industries Research and Development Corporation, Canberra, pp. 212-218.

Mary, S.S., and Gopalan, A. 2006. Dissection of genetic attributes yield traits of fodder cowpea in $\mathrm{F}_{3}$ and $\mathrm{F}_{4}$. Journal of Applied Sciences Research. 2: 805-808.

Morton, J.F. 1967. The balsam pear an edible medicinal and toxic plant. Economic Botany. 212: 57-68.

Narayan, R., Ahmed, N., and Mufti, S. 2006. Evaluation of some bitter gourd genotypes for yield traits and genetic parameters under Kashmir conditions. Environment and Ecology. 24 (3A): 750-752.

Panse, V.G., and Shukhatme, P.V. 1967. Statistical methods for agriculture workers ( $2^{\text {nd }}$ Eds.). Indian Council of Agriculture Research, New Delhi.

Pathak, M., Manpreet, and Pahwa, K. 2014. Genetic variability, correlation and path coefficient analysis in bitter gourd (Momordica charantia L.). International Journal of Advanced Research. 2(8):179184.
Raja, S., Bagle, B.G., and Dhandar, D.G. 2007. Genetic variability studies in bitter gourd for zero irrigated condition of semi-arid ecosystem, Indian Journal of Horticulture. 64(4): 425-429.

Resmi, J., and Sreelathakumary, I. 2012. Multivariate analysis of the genetic diversity of bitter gourd (Momordica charantia L.). Vegetable Science. 39(1): 2630.

Shukla, S., Bhargava, A., Chatterjee, A., Srivastava, A., and Singh, S.P. 2006. Genotypic variability in vegetable amaranth (Amaranthus tricolor L.) for foliage yield and its contributing traits over successive cuttings and years. Euphytica. 151(1):103110.

Singh, V., Rana, D.K., and Shah, K.N. 2017. Genetic variability, heritability and genetic advance in some strains of bitter gourd (Momordica charantia L.) Under subtropical conditions of Garhwal Himalaya. Plant Archives. 17(1): 564-568.

Yadagiri, J., Gupta, N.K., Tembhire, D., and Verma, S. 2017. Genetic variability, heritability and morphological characterization in bitter gourd (Momordica charantia L.). International Journal of Pure and Applied Bioscience. 5(4): 1322-1327.

Yadav, M., Pandey, T.K., Singh, D.B., and Singh, G.K. 2013. Genetic variability, correlation coefficient and path analysis in bitter gourd, Indian Journal of Horticulture. 70(1): 144149.

\section{How to cite this article:}

Nidhi Tyagi, V.B. Singh and Praveen Kumar Maurya. 2018. Studies on Genetic Variability, Heritability and Genetic Advance in Bitter Gourd (Momordica charantia L.) for Yield and Yield Contributing Traits. Int.J.Curr.Microbiol.App.Sci. 7(03): 1788-1794.

doi: https://doi.org/10.20546/ijcmas.2018.703.210 